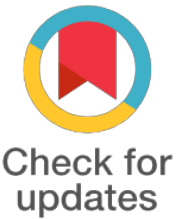

*For correspondence:

syo117sy@naver.com

Competing interests: The authors declare that no competing interests exist.

Received: 2017-03-06

Accepted: 2017-06-04

Published: 2017-09-05

Copyright The Author(s) 2017. This article is published with open access by BioMedPress (BMP).

This article is distributed under the terms of the Creative Commons Attribution License (CC-BY 4.0) which permits any use, distribution, and reproduction in any medium, provided the original author(s) and the source are credited.

POSTER

\title{
Oxygen carrier containing microparticles for prolonged cell survival and effective bone regeneration
}

\author{
So Yeong Kim, Ho Yong Kim, June-Ho Byun, Jin Ho Lee, Se Heang Oh \\ Dankook University 119, Dandae-ro, Dongnam-gu \\ Cheonan-si, Chungcheongnam- Do 31116, South Korea
}

\section{Abstract}

The organ transplantation is considered as an effective therapeutic method for organ failure. However, the shortage of donor organ and the immunological rejection are still remained as a big huddle in clinical fields. As an alternative, the tissue-engineering approach for functional organ replacement is extensively studied. The $3 \mathrm{D}$ porous scaffolds which guide growth and differentiation of cells are widely utilized as a vital factor with autologotic cells and growth factors for tissue engineering. However, cell necrosis in the center of $3 D$ cell scaffold, due to the insufficient oxygen diffusion is considered as critical limitation for the formation of ${ }_{3} D$ tissues. Recently, various oxygen delivering/releasing materials have been studied to overcome this limitation. In this study, we developed a perfluorooctane (PFO)-loaded hollow microparticles (PFO-HP) which can allow sustained oxygen delivery for sufficient period, and thus provide appropriate environment for cell survival even in hypoxia. Cell (human periosteum-derived cell, hPDC) behaviors (proliferation, apoptosis, protein synthesis, etc.) in hypoxia ( $1 \% \mathrm{O}_{2}$ and $5 \%$ $\mathrm{CO}_{2}$ ) were evaluated for 28 days. And osteogenic differentiation of cell [alkaline phosphatase (ALP activity), calcium deposition, immunocytochemistry, and RT-PCR (RUNX2, collagen type I, osteocalcin, osteonectin)] after 10 days exposure in hypoxic condition was also investigated. New bone formation (histology, CT) of the cell-loaded PFO-HP and PBS-HP was also investigated using a miniature pig (mandibular defect model).

\section{Keywords}

Perfluorooctane, oxygen carrier, hypoxia, cell survival, osteogenic differentiation

\section{Funding}

This work was supported by a grant of the Korea Health Technology R\&D Project through the Korea Health Industry Development Institute (KHIDI), founded by the Ministry of Health \& Welfare, Republic of Korea (grant number : Hl12 $\mathrm{C}_{1596) .}$

\section{References}

